\title{
Nurses' Knowledge And Practice Regarding Patients With Posttraumatic Hypovolemic Shock
}

\author{
Dr. Amal Bakr Abo El-Ata; Dr. hayat Mohammed ahmed; Nabila Abd El-aziz \\ Mohammed
}

Assistant professor of medical surgical nursing - Faculty of Nursing Port Said

University; Lecturer of Medical Surgical nursing - Faculty of Nursing - Port Said

University; B.Sc. Nursing, 2010 - Faculty of Nursing - Mansoura University

\begin{abstract}
Background: Hypovolemic shock is a severe life threatening emergency affecting all organ systems. Nurses play a vital role in caring of patients with post traumatic hypovolemic shocked. Aim: Assess nurses 'knowledge and practice regarding patients with post traumatic hypovolemic shock. Subjects and Method: A descriptive research design was used. Setting: The study was conducted in intensive care unit in Damietta general hospital and port-said governmental hospitals Subjects: A convenient sample of 50 nurses participated in the study Tools: data was collected using two tools, Nurses' Knowledge questionnaire and observational check list for nurses' practice. Results: The result of study indicated that $54 \%$ of studied nurses had satisfactory knowledge while $66 \%$ had satisfactory practice Conclusion: More than half of the studied nurses had satisfactory knowledge and practice regarding patients with post traumatic hypovolemic shocked. Recommendations: There are obvious needs for conducting in-service educational and training programs to improve nurses' knowledge and practice regarding patients with post traumatic hypovolemic shock.
\end{abstract}

Key Words: Nurses' knowledge, practice, post traumatic, Hypovolemic shock. 


\section{INTRODUCTION}

The exact of hypovolemic shock is not known because it is a response rather than disease it is common complication among hospitalized patient in emergency department and after surgery or invasive procedure (Semerci et al., 2018)., Every years around 5.8 million people die worldwide due to events related trauma leading to death and disability about 40 percent of trauma related death are due to hemorrhage (Jacob \& Kumar,2014).

Hypovolemic shock is the most common type of shock which result from the loss of circulating blood volume this may result depletion of body fluid. (Siddal , Khatri \& Radhakrishnan ,2017). So, blood carries oxygen and oxygen is required to keep the body tissue and cells alive if insignificant amount of blood is lost internally or externally the cells will not receive the amount of oxygen the need to further more the west product of oxygen metabolism (carbon dioxide) that return to the heart and lung via the blood for elimination from the body will build up in the cells and organs leading to cell or organ death (Escobar et al., 2017).

The conditions are leading to hypovolemic shock include burns, trauma , hemorrhage and surgery burns lead to loss of plasma but hemorrhage and trauma leading to blood loss internally or externally ( Shin et al ., 2015).

Hypovolemic shock progressive to four stage when the condition that cause shock remain uncorrected and poor cellular oxygenation continues. Moreover, identify sign and symptoms (Fröhlich et al., 2016). each stage help in treatment first stage are heart rate 90 beat minute ,normal blood pressure, urine output more than $30 \mathrm{ml}$ per $\mathrm{hr}$, second stage heart rate 110,normal blood pressure, urine output 20-30 ml per hr or third stage heart rate more than $120 \mathrm{bm}$, hypotension, tachypnea and urine output 5 to $15 \mathrm{ml}$ per hour or four stage heart rate more than 140 beat minute, very decrease blood pressure ,respiratory rate more than 35 breath per minute, negligible urine output ,patient confused and lethargic. Also, depending on cause of hypovolemic shock may be of following type hemorrhagic shock, dehydration shock and traumatic shock (Morrison,Galgon\& Jansen,2016).

Principle of managing patient with hypovolemic shock focus on stopping the loss of fluid and restoring the circulating volume the health care team work to gather 
and collaborates improviding the appropriate care quickly for hypovolemic shocked patient effective collaboration and clear communication are essential in providing the patient with positive outcome. (Rahman, Ahmad, Kareem \& Mohammed ,2016).

The nurse play an important role in give first aid post traumatic hypovolemic shocked patient by ensure patent airway, insert intravenous catheter administer oxygen as doctor order, when bleeding is present apply direct pressure to the site increase level of intravenous fluid as doctor order assess level of consciousness and vital signs and interpret laboratory values which help in identify hypovolemic condition. (Workman et al., 2015) Furthermore, incorrect fluid volume loss by administer intravenous fluid and blood product as doctor order and close monitor patient urine output and maintain effective tissue perfusion by given oxygen as doctor order to maintain normal pulse oximatery, place patient in trend lenberg position give medication as doctor order (Baumle, Duncan \& White,2013).

Addition, nursing management for patient during fluid replacement through monitoring of patient for serious side effect of fluid replacement cardiovascular over load and pulmonary edema (Brunner \&suddarth, 2012) nursng role in management hypovolemic shocked help in prevent serious complication as acute respiratory distress syndrome ,acute tubular necrosis disseminated intravascular coagulation or multiple organ dysfunction syndrome. (Williams \& wilkins, 2014).

\section{Significance of study:}

Globally traumatic injuries account for $9 \%$ of mortality and $12 \%$ of the global burden of disease for disability (Mahran, Farouk, Qayed, \& Berraud ,2016) In Egypt trauma is hidden epidemic problem and the top ten leading causes of death in worldwide by 2030in Egypt injuries burden is significant assist was the fifth leading cause of death .(Mahran,Farouk, Qayed\&Berraud,2013)Nurse's workings in intensive care unit paly an important role in management post traumatic hypovolemic shocked patient which help in decrease mortality rate and prevent complication they may have lack in knowledge and improper practice regarding post traumatic hypovolemic shocked patient .Therefor the study may explore the nurses malpractice and lack of knowledge about post traumatic hypovolemic shocked patient. 


\section{AIM OF THE STUDY:}

This study aims to assess nurses' knowledge and practice regarding patients with post traumatic hypovolemic shock

\section{Research questions}

To fulfill the aim of the study, four research questions are formulated.

1. What is the level of knowledge among nurses regarding patients with post traumatic hypovolemic shock?

2. What is the level of practice of nurses dealing with patients with post traumatic hypovolemic shock?

\section{SUBJECTS AND METHOD:}

\section{Research Design:}

A descriptive study design was used to conduct the study.

\section{Study Setting:}

This study was conducted at intensive care unit in Damietta general hospital and Port-said governmental hospitals (Port- said general hospital and Elzhour hospital)

\section{Population and Sample:}

A convenient sample of available nurses (50) working in previous munched setting Damietta general hospital was 22 nurses, port-said general hospital 18 nurses and ELzhour 10 nurse).

\section{Tools of data collection:}

\section{Tool I: Nurses' knowledge questionnaire:}

It was developed by the researcher after reviewing of recent related literature Burner \& suddarth,2012; Jacob \& kumar, 2014 to assess nurses' knowledge regarding patients with post traumatic hypovolemic shock. It includes two parts 


\section{Part (1): Demographic data and work related data for studied nurses}

This part includes 6 closed ended questions related to characteristics of the studied nurses' as age, gender, educational level and work related data as hospital name, years of experience, and training courses.

\section{Part (2): Nurses' Knowledge questions}

This part consisted 29 closed ended questions in the form of true and false ,including Nurses' knowledge regarding Definition, diagnostic studies, causes, sign and symptoms, medical management, classification, physical examination, emergency care, fluid resuscitation, complication and nursing care for posttraumatic hypovolemic shock

\section{Scoring system for nurses' knowledge}

Total nurse's knowledge regarding patients with post traumatic hypovolemic shock 029 grades and it was considered that $<70 \%$ of total grades was considered unsatisfactory nurse's knowledge about posttraumatic hypovolemic shock $\quad(<20$ grades) and $\geq 70 \%$ of total grades was considered satisfactory nurse's knowledge about posttraumatic hypovolemic shock ( $\geq 20$ grades) (Nageh, 2017).

\section{Tool (II): Nurses' Practice Observational checklist}

This tool was developed by the researcher based on standardized nursing skills reviewed related literature, Lynn, 2015; Potter, Patricia, \& Perry, 2013; Timby \& Smith, 2014) to assess nurses' practice regarding care of patients with post traumatic hypovolemic shocked patient, for example ensure patent airway 2 items, assess level of conscious 3 items, place patient in trendlenberge position 8 items, connect pulse oximater 13 items ,give oxygen therapy 12 items, give fluid as doctor order 13 items, insert two large pare cannula for patient 18 items, monitor intake and output 3 items , insert urinary catheter 27 items, and give blood transfusion 22 items .

\section{Scoring system for nurses 'observation practice}

For Nurses' observational checklist, score one was given for complete done while not done was given zero .Total score were 0-129 grades. The nurse had satisfied practice 
when the total score equal or above $70 \%$ ( $\geq 90$ grades $)$ and unsatisfied if blow $70 \%(<90$ grades) (Nageh, 2017) .

\section{validity}

IT ascertained by ajury of 11 experts from nursing and medical staff and medicine from (internal medical and external medical) who review the tools for clarity, relevance, comprehensiveness, understandable and applicable and ease for implementation, according to their opinion modifications were applied.

\section{Reliability:}

Alpha Cronbach test was used to measure the internal consistency of the tool for knowledge (.822) and for practice (.911).

\section{Pilot study:}

The pilot study was carried out after development of data collection tools. It was applied on $10 \%$ of the total sample (5 nurses) and was conducted one month before embarking on the field of working of the study. The purpose of the pilot study was to test the applicability, clarity and feasibility of the study tools and to estimate the proper time required for filling it out each tool. Appropriate modification was done according to the results of pilot study. The nurses in the pilot study were not included in the main sample.

\section{Field work:}

Data were collected from the selecting setting by the researcher using the preconstructed from June 2018 to January 2019. Data were collected six days weekly. The eligible nurse was invited to participate, and upon acceptance, she/he was handed a questionnaire form for filling it out. This took between 20-30 minutes. The process of observation was then done during the regular work of the nurse using the observation checklist regarding care for post traumatic hypovolemic shocked patient.

\section{ADMINISTRATIVE DESIGN:}

An official written permission to conduct the study was obtained from the director of the previously mentioned setting. In addition to verbal explanation of the 
nature and aim of the study was performed to medical and nursing staff at intensive care units.

\section{Ethical considerations:}

The aim of the study was simply explained to the nurses. An oral explanation was obtained from nurses who agree to participate in the study prior to data collection. They were assured that anonymity and confidentiality would be guaranteed and the right of nurses to withdraw at any time. Ethics, values, culture and beliefs was respected

\section{Statistical Design:}

Data entry and statistical analysis were done using SPSS statistical software package(version 24). Data were presented using statistics in the form

of frequencies and percentages for qualitative variables.

\section{RESULTS:}

Table (1): shows that more than half of studied nurses $(60 \%)$ in age group from 20 to less than 30 years old. The most of the studied nurses (90\%) were female and (78\%)of the studied nurses graduated from technical school of nursing.

Table (2): shows that less than half of studied nurses (44\%) worked at Damietta general hospital, $48 \%$ of the studied nurses had less than 5 years of experience and $56 \%$ of the studied nurses get training courses about hypovolemic shock.

Table (3): Proved that there were no statistically significant correlation between total scores of nurse's knowledge and practice regarding care of post traumatic hypovolemic shock patient with $\mathrm{p}<0.050$

Table (4): Shows that there was statistical significant relation between hospital name and total nurses' knowledge regarding post traumatic hypovolemic shock patient .

Table (5): demonstrates that, there was not statistically significant relation between nurses' practice and sex, age, level of education \& marital status of studied nurses regarding posttraumatic hypovolemic shock patient. 
Figure (1): Shows that $54 \%$ of the studied nurses had satisfactory total knowledge regarding care for patient with post traumatic hypovolemic shocked.

Figure (2): Demonstrate that $66 \%$ of studied nurses had satisfactory and $34 \%$ had unsatisfactory total practice regarding patient with post traumatic hypovolemic shocked.

Table 1: Demographic characteristic of nurses in the study sample $(n=50)$

\begin{tabular}{||l||c|c||}
\hline \multicolumn{2}{||l||}{ No. } & \%n \\
\hline \hline Age & 30 & 60.0 \\
\hline $20<30$ years & 18 & 36.0 \\
\hline $30<40$ years & 2 & 4.0 \\
\hline $40<50$ years & \multicolumn{2}{||}{} \\
\hline Gender & 5 & 10.0 \\
\hline Male & 45 & 90.0 \\
\hline Female & 20 & 40.0 \\
\hline Educational level & 19 & 38.0 \\
\hline Nursing school diploma & 10 & 20.0 \\
\hline Nursing institute & 1 & 2.0 \\
\hline Bachelor of nursing & \multicolumn{2}{||}{} \\
\hline Other &
\end{tabular}

Table 2: job characteristic of nurses $n=50$

\begin{tabular}{||l||l|l||}
\hline \multirow{2}{*}{ Work related data } & N=80 & \multicolumn{2}{l|}{} \\
\cline { 2 - 3 } & No. & \\
\hline Hospitals & 22 & 44.0 \\
\hline \hline Damietta Hospital & 18 & 32.0 \\
\hline Port Said general hospital & 10 & 20.0 \\
\hline ELzohour hospital & \multicolumn{2}{|l|}{} \\
\hline Years of experience: & 24 & 48.0 \\
\hline$<5$ years & 12 & 24.0 \\
\hline $5<10$ years & 14 & 28.0 \\
\hline 10 years or more & 22 & 44.0 \\
\hline Receiving special training course & 28 & 56.0 \\
\hline No & & \\
\hline Yes & \multicolumn{2}{|l|}{} \\
\hline
\end{tabular}


Table (3):Correlation between nurses knowledge regarding patient with post traumatic hypovolemic shocked and observational checklist nurses' practice regarding patient with post traumatic hypovolemic shocked $(\mathrm{n}=50)$

\begin{tabular}{||l|c|c||}
\hline \multirow{2}{*}{} & \multicolumn{2}{|c|}{$\begin{array}{c}\text { Nurses knowledge regarding } \\
\text { patient with post traumatic } \\
\text { hypovolemic shocked }\end{array}$} \\
\cline { 2 - 4 } & $\mathbf{R}$ & $\mathbf{P}$ \\
\hline Hand washing & -0.073 & 0.616 \\
\hline Prepare equipment & 0.094 & 0.517 \\
\hline Explain procedure to patient & -0.050 & 0.733 \\
\hline Ensure procedure to patient & -0.074 & 0.609 \\
\hline Assess level of conscious & 0.073 & 0.612 \\
\hline Place patient in trend lenberge position & -0.186 & 0.195 \\
\hline Monitor vital signs two hours & 0.083 & 0.566 \\
\hline Insert two large pare cannula & -0.203 & 0.158 \\
\hline Connect patient pulse oximeter & -0.052 & 0.612 \\
\hline Give oxygen therapy as doctor order & -0.193 & 0.179 \\
\hline Insert urinary catheter to patient & 0.077 & 0.597 \\
\hline Give fluid therapy as doctor order & -0.008 & 0.958 \\
\hline Give blood as doctor order & 0.053 & 0.715 \\
\hline Monitor intake and output to patient & 0.000 & 1.000 \\
\hline Overall Practice & -0.068 & 0.638 \\
\hline \hline
\end{tabular}

r: Pearson coefficient 
Table (4): Relation between overall knowledge and socio - demographic and work data

\begin{tabular}{|c|c|c|c|c|c|c|}
\hline & \multicolumn{4}{|c|}{ "Overall knowledge } & \multirow{3}{*}{$\chi^{2}$} & \multirow{3}{*}{$\mathbf{P}$} \\
\hline & \multicolumn{2}{|c|}{$\begin{array}{c}\text { Unsatisfactory }<70 \% \\
(\mathbf{n}=\mathbf{2 3})\end{array}$} & \multicolumn{2}{|c|}{$\begin{array}{c}\text { Satisfactory } \geq 70 \% \\
(n=27)\end{array}$} & & \\
\hline & No. & $\%$ & No. & $\%$ & & \\
\hline \multicolumn{7}{|l|}{ Hospital name } \\
\hline ل دمياط العام & 16 & 69.6 & 6 & 22.2 & \multirow{4}{*}{$13.957^{*}$} & \multirow{4}{*}{$\begin{array}{l}{ }^{\mathrm{MC}} \mathrm{p}= \\
0.003^{*}\end{array}$} \\
\hline بورسعيد العام & 1 & 4.3 & 11 & 40.7 & & \\
\hline الز هور & 3 & 13.0 & 5 & 18.5 & & \\
\hline بور فؤاد & 3 & 13.0 & 5 & 18.5 & & \\
\hline \multicolumn{7}{|l|}{ Sex } \\
\hline Male & 1 & 4.3 & 4 & 14.8 & \multirow{2}{*}{1.512} & \multirow{2}{*}{$\begin{array}{l}{ }^{F E} \mathrm{p}= \\
0.357\end{array}$} \\
\hline Female & 22 & 95.7 & 23 & 85.2 & & \\
\hline \multicolumn{7}{|l|}{ Age (years) } \\
\hline $20-<30$ & 14 & 60.9 & 16 & 59.3 & \multirow{4}{*}{2.338} & \multirow{4}{*}{$\begin{array}{l}{ }^{\mathrm{MC}} \mathrm{p}= \\
0.338\end{array}$} \\
\hline $30-<40$ & 7 & 30.4 & 11 & 40.7 & & \\
\hline $40-<50$ & 2 & 8.7 & 0 & 0.0 & & \\
\hline $50-60$ & 0 & 0.0 & 0 & 0.0 & & \\
\hline \multicolumn{7}{|l|}{ Level of education } \\
\hline دبلوم تمريض & 12 & 52.2 & 8 & 29.6 & \multirow{4}{*}{6.057} & \multirow{4}{*}{$\begin{array}{l}{ }^{\mathrm{MC}} \mathrm{p}= \\
0.082\end{array}$} \\
\hline معهد فني صحي / تمريض & 5 & 21.7 & 14 & 51.9 & & \\
\hline بكالوريوس تمريض | & 6 & 26.1 & 4 & 14.8 & & \\
\hline اخري & 0 & 0.0 & 1 & 3.7 & & \\
\hline \multicolumn{7}{|l|}{ Marital status } \\
\hline Single & 2 & 8.7 & 6 & 22.2 & \multirow{4}{*}{4.430} & \multirow{4}{*}{$\begin{array}{l}{ }^{\mathrm{MC}} \mathrm{p}= \\
0.124\end{array}$} \\
\hline Married & 18 & 78.3 & 21 & 77.8 & & \\
\hline Divorced & 3 & 13.0 & 0 & 0.0 & & \\
\hline Widow & 0 & 0.0 & 0 & 0.0 & & \\
\hline \multicolumn{7}{|l|}{ Years of experience } \\
\hline$<5$ & 9 & 39.1 & 15 & 55.6 & \multirow{4}{*}{$\begin{array}{l}\square= \\
4.445\end{array}$} & \multirow{4}{*}{$\begin{array}{l}{ }^{\mathrm{MC}} \mathrm{p}= \\
0.211\end{array}$} \\
\hline $5-10$ & 5 & 21.7 & 7 & 25.9 & & \\
\hline $10-15$ & 2 & 8.7 & 3 & 11.1 & & \\
\hline$\geq 15$ & 7 & 30.4 & 2 & 7.4 & & \\
\hline \multicolumn{7}{|l|}{\begin{tabular}{|l} 
Have you attended special \\
courses to take care of a \\
patient's shock after a \\
lack of fluid volume after \\
accidents
\end{tabular}} \\
\hline No & 11 & 47.8 & 11 & 40.7 & $\square^{\square}=$ & \multirow{2}{*}{0.615} \\
\hline Yes & 12 & 52.2 & 16 & 59.3 & 0.253 & \\
\hline
\end{tabular}

$\chi^{2}$ : Chi square test MC: Monte Carlo FE: Fisher Exact

$\mathrm{p}$ : $\mathrm{p}$ value for association between different categories

*: Statistically significant at $\mathrm{p} \leq 0.05$ 
Table (5): Relation between overall practice and socio - demographic and work related date

\begin{tabular}{|c|c|c|c|c|c|c|}
\hline & \multicolumn{4}{|c|}{ Overall practice } & \multirow{3}{*}{$\chi^{2}$} & \multirow{3}{*}{$\mathbf{P}$} \\
\hline & \multicolumn{2}{|c|}{$\begin{array}{c}\text { Unsatisfactory }<70 \% \\
(\mathbf{n}=17)\end{array}$} & \multicolumn{2}{|c|}{$\begin{array}{c}\text { Satisfactory } \geq 70 \% \\
(n=33)\end{array}$} & & \\
\hline & No. & $\%$ & No. & $\%$ & & \\
\hline Hospital name & & & & & \multirow{5}{*}{5.349} & \multirow{5}{*}{$\begin{array}{l}{ }^{\mathrm{MC}} \mathrm{p}= \\
0.144\end{array}$} \\
\hline | دمياط العام | & 9 & 52.9 & 13 & 39.4 & & \\
\hline بورسعيد العام & 5 & 29.4 & 7 & 21.2 & & \\
\hline 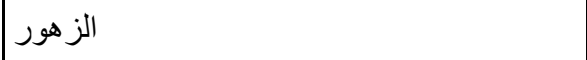 & 0 & 0.0 & 8 & 24.2 & & \\
\hline بور فؤاد & 3 & 17.6 & 5 & 15.2 & & \\
\hline Sex & & & & & \multirow{3}{*}{0.089} & \multirow{3}{*}{$\begin{array}{l}{ }_{\mathrm{FE}}^{\mathrm{p}}= \\
1.000\end{array}$} \\
\hline Male & 2 & 11.8 & 3 & 9.1 & & \\
\hline Female & 15 & 88.2 & 30 & 90.9 & & \\
\hline Age (years) & & & & & \multirow{5}{*}{0.596} & \multirow{5}{*}{$\begin{array}{l}{ }^{\mathrm{MC}} \mathrm{p}= \\
1.000\end{array}$} \\
\hline $20-<30$ & 10 & 58.8 & 20 & 60.6 & & \\
\hline $30-<40$ & 6 & 35.3 & 12 & 36.4 & & \\
\hline $40-<50$ & 1 & 5.9 & 1 & 3.0 & & \\
\hline $50-60$ & 0 & 0.0 & 0 & 0.0 & & \\
\hline Level of education & & & & & \multirow{5}{*}{1.304} & \multirow{5}{*}{$\begin{array}{l}{ }^{\mathrm{MC}} \mathrm{p}= \\
0.822\end{array}$} \\
\hline | & 6 & 35.3 & 14 & 42.4 & & \\
\hline معهد فني صحي / تمريض | & 8 & 47.1 & 11 & 33.3 & & \\
\hline بكالوريوس تمريض | & 3 & 17.6 & 7 & 21.2 & & \\
\hline اخري & 0 & 0.0 & 1 & 3.0 & & \\
\hline Marital status & & & & & \multirow{5}{*}{0.484} & \multirow{5}{*}{$\begin{array}{l}{ }^{\mathrm{MC}} \mathrm{p}= \\
0.864\end{array}$} \\
\hline Single & 2 & 11.8 & 6 & 18.2 & & \\
\hline Married & 14 & 82.4 & 25 & 75.8 & & \\
\hline Divorced & 1 & 5.9 & 2 & 6.1 & & \\
\hline Widow & 0 & 0.0 & 0 & 0.0 & & \\
\hline Years of experience & & & & & & \\
\hline$<5$ & 8 & 47.1 & 16 & 48.5 & & \\
\hline $5-10$ & 4 & 23.5 & 8 & 24.2 & $\square^{\square}=$ & ${ }^{\mathrm{MC}} \mathrm{p}=$ \\
\hline $10-15$ & 1 & 5.9 & 4 & 12.1 & 0.931 & 0.849 \\
\hline$\geq 15$ & 4 & 23.5 & 5 & 15.2 & & \\
\hline $\begin{array}{l}\text { Min. - Max. } \\
\text { Mean } \pm \text { SD. }\end{array}$ & \multicolumn{2}{|c|}{$\begin{array}{l}0.25-27.0 \\
8.13 \pm 8.38\end{array}$} & \multicolumn{2}{|c|}{$\begin{array}{l}0.01-21.0 \\
6.55 \pm 6.09\end{array}$} & $t=0.766$ & 0.447 \\
\hline $\begin{array}{l}\text { Have you attended special courses to } \\
\text { take care of a patient's shock after a } \\
\text { lack of fluid volume after accidents } \\
\text { No } \\
\text { Yes }\end{array}$ & $\begin{array}{c}7 \\
10\end{array}$ & $\begin{array}{l}41.2 \\
\mathbf{5 8 . 8}\end{array}$ & $\begin{array}{l}15 \\
18\end{array}$ & $\begin{array}{l}45.5 \\
\mathbf{5 4 . 5}\end{array}$ & $\begin{array}{l}\square= \\
0.083\end{array}$ & 0.773 \\
\hline
\end{tabular}

\section{t: Student t-test}

$\mathrm{p}$ : $\mathrm{p}$ value for association between different categories 
*: Statistically significant at $\mathrm{p} \leq 0.05$

\section{Total nurses knowledge regarding patient with post traumatic hypovolemic shock}

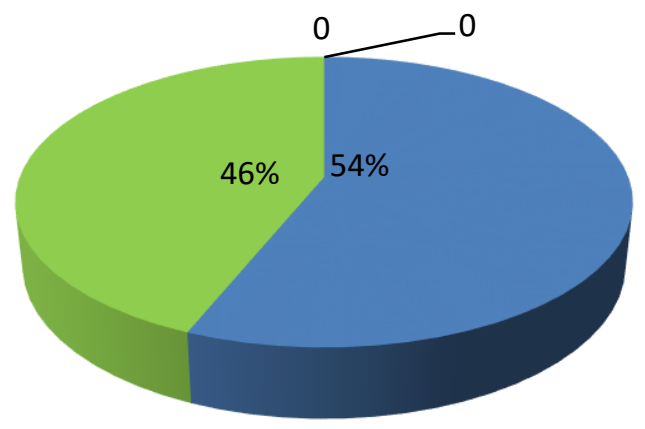

Figure (1): total nurses 'knowledge regarding care for patient with post traumatic hypovolemic shocked $(\mathrm{n}=50)$.

\section{Total nurses ' practice regarding patient with post traumatic hypo volemic shock}

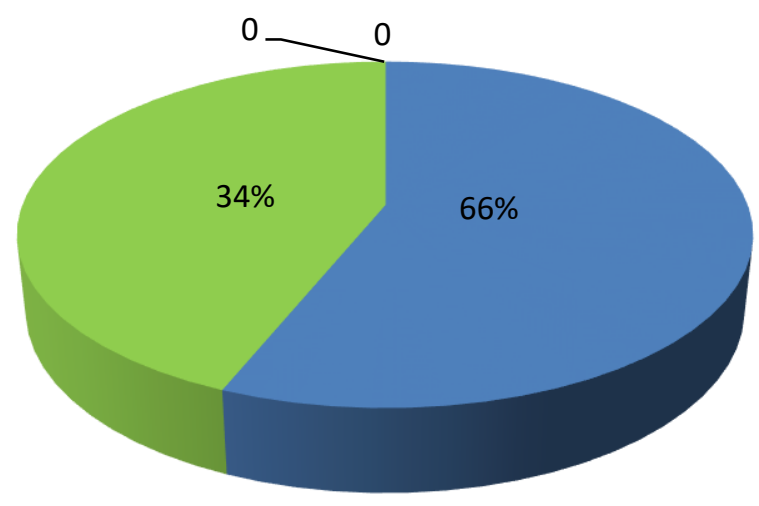

Figure (2): Total of the studied nurses 'practice regarding care for patient with post traumatic hypovolemic shocked $(n=50)$. 


\section{DISCUSSION:}

Hypovolemic shock is life threating condition caused by an inadequate intravascular volume this can be due to loss of blood or other body fluids. Hypovolemic shock is the most common type of shock experienced in patient who suffers from traumatic injury. IT occurse as the result from volume failure (Gulati, 2016).

Nursing care focuses on assisting with treatment causes hypovolemic shock and restoring intravascular volume through oxygen administration to increase the amount of oxygen carried by available hemoglobin in the blood, safe administration of the blood, monitor vital signs of patients with deficit fluid volume and safe administration of fluids the nurse should monitor the patient for cardiovascular over load and sing of difficulty in breathing pulmonary edema ,jugular vein distention and laboratory result and nurse play important role is assess fluid intake and output ( Williams \& wilkins, 2014)

The present study revealed that about more than half of studied nurses in age group from 20 to 30years old and most of them were female and two fifth of them were graduate from nursing diploma graduated from technical school of nursing.

The current study reported that half of studied nurses their experience were less than 5 years and more than half of these who attended special courses to take care of patient is shock after lack of fluid volume after accident.

The finding of the present study denoted that more than half of studied nurses had satisfactory knowledge regarding care of patients with post traumatic hypovolemic shock . the study agree with (Al-Ganmi \& Hussein,2014) who repearted that most of studied nurses had satisfactory level in knowledge regarding care of patient with cardiogenic shock .

The current study showed that the more half of the nurses had satisfactory knowledge regarding post traumatic hypovolemic shock. This is obviously detected as the majority of them had correct knowledge regarding to sign and symptoms post traumatic hypovolemic shock and physical examination for posttraumatic hypovolemic shock, diagnostic studies for posttraumatic hypovolemic shock patient but most of them 
correct knowledge regarding to causes of post traumatic hypovolemic shock and emergency care for post traumatic hypovolemic shock .

The reasons for satisfactory of nurses' knowledge regarding from researcher " point of view", this might be related to more half of studied nursing attend training program about care for post traumatic hypovolemic shock patient. Which effect in nurses knowledge score about care for post traumatic hypovolemic shock patient the researcher point of views is supported by (Leshimi ,daud \& zuikifli,2009)who mentioned that nurses need to improve their knowledge especially nurses knowledge before and during and health education . as responsibility for care of patient lies in the hands of nurses. Therefore for nurses to provide high quality care and function effectively . the nureses must have an adequate knowledge that they have actually used in practice .(kasem,2016)

Nurse's needs good knowledge to maintain their skill, knowledge and competencies, continuing professional development is critical to maintaining the high standards expected from the nursing professions .IT is also essential that clinical skills are maintained through participation in ongoing nursing education and professional development actives.( who2013).

On assessing the actual nurses practice regarding patient with post traumatic hypovolemic shocked of the present study has revealed that the most of the studied nurses satisfied practice about care for post traumatic hypovolemic shock patient this result was congruent with (Shobowale, Adegunle \& Onyedibe ,2016) who found that one third of nurse had satisfied level of practice related to hand washing when dealing with patient in intensive care unit

Concerning total scores of nurses ' practice, the present study showed that the most of studied nurses had satisfactory total practice regarding care for post traumatic hypovolemic shock patient. From the researcher "point of view ", the might be due to the highest percentage of the studied nurses were juniors. The advantage of nurses in young age group are being hyperactive which is always required in such crucial and vital wards . This justification discussed in previous study (Arathy ,2011).

In the light of the present study findings, there were negative no statistically significant correlations between total scores of nurses' knowledge and practice 
regarding care of post traumatic hypovolemic shock patients. From the researcher "point of view", These findings might be related to more than half of studied nurses had satisfactory total knowledge and practice regarding care of post traumatic hypovolemic shock patients which can positive affect patient safety and education. Training is considered one way of preventing adverse nursing outcomes. So, to provide high quality care, nurses must have an adequate knowledge that they have actually used in practice. These study agree with (Eldsouky, Taha \& Saleh ,2016). mentioned that there was no statistically significant correlation between total scores of nurses' knowledge and practice regarding to fluid and electrolyte balance among patients with congestive heart failure .

As regarded to relation between nurses' knowledge regarding post traumatic hypovolemic shock and socio-demographic and work related data, there were not statistically significant relations between total nurses' knowledge and sex, age, level of education, marital status, years of experience, and attending training program. Meanwhile there was statistical significant relation between total nurses' knowledge and hospital name regarding care of post traumatic hypovolemic shock patients This result disagree with(Al-Ganmi \& Hussen,2014) ). mentioned that there were not statistically significant relations between total nurses' knowledge and attending training program. Meanwhile there was high statistical significant relation between total nurses' knowledge and ages, gender, level of education, years of experience in cardiac care unit regarding care of patient with cardiogenic shock.

As regarded to relation between Nurses' practice regarding post traumatic hypovolemic shock and socio-demographic and work related data, there were not statistically significant relations between total nurses' practice and sex, age, level of education, marital status, years of experience, hospital name and attending training program. It is possible that there were minimal changes in practice in some of the studies discussed because of the timescale. Change in practice takes time and future studies should look at change over a longer period.

Say in this study there's appositive factors have appositive effect on nursing performance for post traumatic hypovolemic shock. Therefore we must continuous follow-up and training to improve nursing care

\section{CONCLUSION:}


Based on the findings of the current study, it can be concluded that More than half of the studied nurses had satisfactory and most of studied nurses had satisfactory level of nurses' practice of regarding patient with post traumatic hypovolemic shocked.

\section{RECOMMENDATIONS:}

\section{In the light of the study results, the following recommendations are proposed:}

Provide nurses with periodic training sessions and evaluations to improve their knowledge and practices regarding post traumatic hypovolemic shocked

\section{REFERENCES:}

Al-Ganmi, A. H. A.(2014). Assessment of Nurses' Knowledge Concerning Cardiogenic shock for Patients' in Cardiac Care Unit at Baghdad Hospitals.

Arathy, S. R. (2011). A study to assess the knowledge and practices among cardiac nurses about patient's safety after cardiac catheterization code No6210availabe

\section{:https://www.sciencedirect.com/science/article/abs/pii/S00256196116085 accessed at 10}

\section{July, 2019.}

Baumle w., Duncan G., White L. (2013).medical surgical nursing an integrated approach,3rd ed., united state of America, cengage learning, P. p, 80-88.

Burner \& suddarth S.,(2012).text book of conidian medical surgical nursing , $2^{\text {nd }}$. Canada Lippincott, Pp. 350-360.

EscobarM. F., Füchtner, C. E., Carvajal, J. A., Nieto, A. J., Messa, A., Escobar, S. S., \&

Miller, S. (2017). Experience in the use of non-pneumatic anti-shock garment (NASG) in the management of postpartum hemorrhage with hypovolemic shock in the Foundation Valle Del Lili, Cali, Colombia. Reproductive health, 14(1), 58. 


\section{https://link.springer.com/article/10.1186/s12978-017-0325-2}

Eldsouky, S. E., Taha, N. M., \& Salah, M. D (2016). Nurses 'knowledge and practice concerning fluid and electrolyte balance among patients with congestive heart

Fröhlich, M., Driessen, A., Böhmer, A., Nienaber, U., Igressa, A., Probst, C\& Trauma

Register DGU. (2016). Is the shock index based classification of hypovolemic shock applicable in multiple injured patients with severe traumatic brain injury? An analysis of the Trauma Register DGU®. Scandinavian journal of trauma, resuscitation and emergency medicine, 24(1), 148

Gulati, A.(2016).Vascular endothelium and hypovolemic shock. Current vascular pharmacology, 14(2), 187-195.

Jacob C .M \& Kumar. (2014).The challenge in management of hemorrhage shock in

trauma, medical journal armed forces India, 5(2), 3-6 available at http://www.niddk,n.gov, access at (15-2-2018).

Lexshimi, R.G., Daud, F., and Zulkifli, S. (2009). Knowledge, attitude and practice of nurses in administering oral medication at medical ward, university kebangsaan Malaysia medical center Med \&Health, 4(1): 16-24

Lynn. P., (2015). Taylor's Clinical Nursing Skills, A Nursing Process Approach $4^{\text {th }}$ Ed. Philadelphia: Lippincott Williams \& Wilkins: Pp.; 949-950.

Kasem , M. (2016) .Assessment of nurses' performance regarding nursing care of patients undergoing blood transfusion. Un published Master thesis. Faculty of Nursing,Port said University. Pp. 83:84. 
Mahran, D. G., Farouk, O., Qayed, M. H., \& Berraud, A. (2016). Pattern and trend of injuries among trauma unit attendants in Upper Egypt. Trauma monthly, 21(2).

\section{https://www.ncbi.nlm.nih.gov/pmc/articles/PMC5003474/}

Mahran, D. G., Farouk, O. A., Qayed, M. H., \& Berraud, A. F.(2013). Hospitalized injuries and deaths in a trauma unit in upper Egypt. International journal of critical illness and njury science, 3(4), 235

\section{https://www.ncbi.nlm.nih.gov/pmc/articles/PMC3891188/}

Morrison J .J, Galgon R .E,Jansen.J.O, A. (2016).systematic review of the use of resuscitative endovascular balloon occlusion of the aorta in the management of hemorrhagic shock, trauma Journal, 80(2)324-334.

Nageh ,M . (2017) .Assessment of nurses' performance regarding care of patients undergoing cardiac catheterization . Un published Master thesis. Faculty of Nursing, Port said University. Pp. 70:77.

Potter., Patricia, A., \& Perry, A.G. (2013).Fundamental of nursing $.8^{\text {th }} \mathrm{Ed}$ .Elsevier Mosby. Pp: 605:613.

Rahman, N. H. N., Ahmad, R., Kareem, M. M., \& Mohammed, M. I. (2016). Ultrasonography assessment of inferior vena cava/abdominal aorta diameter index:a new approach of assessing hypovolemic shock class 1. International journal of emergency medicine, $9(1), 8$.

Semerci, E., Durukan, P., Yıldırım, S., Baykan, N., Yakar, Ş., \& İpekten, F. (2018).

Gastrointestinal sistem kanamalı hastalarda şok indeksi ve hematokrit düzeylerinin mortalite üzerine etkisi. akademik gastroenteroloji dergisi ,17(2), 85-89. 
Shin, H. K., HanH. S., Lee, T., Park, D. J., Jung, K., \& Kim, K. (2015). Resuscitative endovascular balloon occlusion of the aorta in a trauma patient with hypovolemic shock. Korean Journal of Critical Care Medicine, 30(2), 115-118.

Siddall, E., Khatri, M., \& Radhakrishnan, J. (2017). Capillary leak syndrome: etiologies, .pathophysiology, and management. Kidney international journal, 92(1), $37-46$

Shobowale, E. O., Adegunle, B., \& Onyedibe, K. (2016). An assessment of hand hygiene practices of healthcare workers of a semi-urban teaching hospital using the five moments of hand hygiene. Nigerian medical journal: journal of the Nigeria Medical Association, 57(3), 150 .

Timby B. \& Smith N., (2014). Introductory Medical -Surgical Nursing, $1111^{\text {th }}$ Ed, Walters Kluwer, Lippincott Williams and Wilkins, Philadelphia Ch:(21),p:317.

Workmen M., Donna D., Ignatavicus. (2015). patient center collaborative care medical surgical nursing, $8^{\text {th }}$ ed, Canada, Elsever, P.p., 747-760.

World Health Organization,(2013). Good practices in nursing and midwifery from expert to expert. A manual for creating country case studies. Available at:

http://www.euro.who.int/data/assets/pdffile/0007/234952/Good-practices-innursing-and-midwifery.pdf.

Williams L and Wilkins.,(2014). essential of path physiology concepts of altered health status, heart failure and circulating shock, ,third edition, china, Wolters Kluwer health,.P.p499. 


\section{معلومات وممارسات التمريض تجاه مرضي صدمه نقص حجم السوائل بعد الحوادث}

\section{الخــلاصة}

تعد صدمه نقص حجم السوائل ما بعد الحوادث حالة طارئة خطيرة تهدد الحياة ونؤثر على جميع أجهزة الجسم .

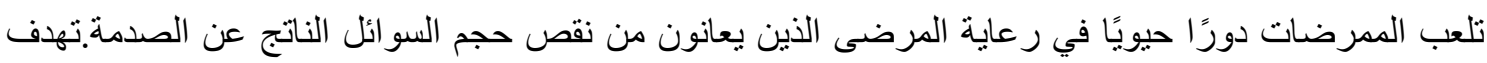
هذه الدراسة النقيبم معلومات وممارسات الممرضين تجاه المرضي المصابين بصدمه نقص حجم الدم ما بعد لهد الحوادث واجريت هذه الدراسة في مستشفيات بورسعيد ومستشفيات دمياط. وقد اشتملت عينة الدراسة على 50 ممرض / ممرضة. وقد جمعت تلك المعلومات عن طريق (استمارةاستيبان لجمع معلومات الممرضين عن مرضى فئي بمستشفى بورسعيدالعام ومستشفي الزهوربمدينة بورسعيد ومستشفى دمياط العام في مدينة دمياط و استمارة ملاحظه لتقبي مممارسات الممرضين تجاه المرضي المصابين بصدمه نقص حجم الدم ما بعد الحوادث. وقداظهرت النتائج ان الممرضين لديهم المعلومات الكافية للتعامل تجاه المرضي المصابين بصدمه نقص حجم الدم ما بعد الحوادث

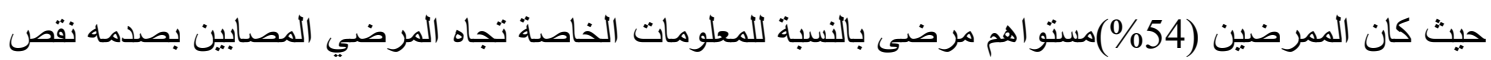
حجم الدم ما بعد الحوادث بينما أكثر من نصف الممرضين(66\%)مستوى ممارساتهم مرضي تجاه المرضي بهي

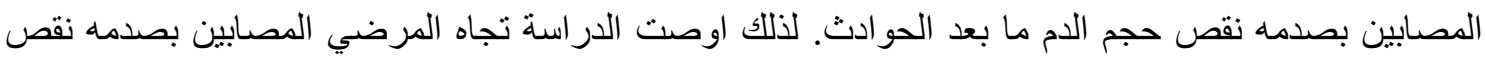
حجم الدم ما بعد الحو ادث و كيفية التعامل معها ضمن المناهج الدراسية لطلبة التمريض و اعطاء العديد من الدورات التدريبية للممرضين بخصوصها

الكلمات المرشدة: معلومات التمريض ، صدمه نقص حجم الدم ما بعد الحو ادث ، ممارسات الممرضين. 